\title{
Rationalizing the Choice of Housing on Cultivable Land: Is Cash-Return the Only Determinant?
}

\author{
*Zobayer Ahmed, Pronab Kumar Saha \\ Sylhet International University, Bangladesh \\ *ahmadzobayer@yahoo.com
}

\begin{abstract}
Society faces numerous problems due to high population growth where housing along with other settlements is a notable concern. Horizontal expansion of housing on cultivable land in rural area reduces the availability of land for cultivation. The study is a combination of both quantitative and qualitative in nature based on primary data, carried out in a village in Comilla, an eastern district of Bangladesh during April 2012. The study finds that the households receive returns both in cash as well as in kind from new homesteads made on cultivable land. The cash benefit received by households at new place is Tk. 156238.14 on an average per year in 2011 price and on an average the cash investment per year in 2011 price (inflation adjusted) for housing is Tk. 213108.1818 (weighted average). This clearly indicates a cash loss from housing on cultivable land from household's perspective. However, statistically the cash investment for housing in rural area is not significantly different from the cash return received by the households at $5 \%$ level of significance. Thus it becomes an important question whether the household's choice of making new home on cultivable land is a rational choice or not. Further, the amount of money each household spent for housing could have been used for a higher cash return through some alternative investments. The study reveals, households derive positive utility (non cash returns) from new homes notwithstanding cash loss and other investment options forgone. The study further argues that if the government or any authority is to take some steps regarding the declining trend of cultivable land in rural areas, the perspectives of the households must be considered with great attention.
\end{abstract}

Keywords: Horizontal Expansion, Housing, Cultivable Land, Non-cash, Return

\section{Introduction}

Bangladesh is a country blessed with a number of natural and other resources though it is one of the densely populated countries in the world, in which $93.51 \%$ of the total areas are comprised of rural areas where $81.27 \%$ of total population inhabits (Barakat et al., 2007). According to a later statistics $71.1 \%$ of total population live in rural areas (Trading Economics, 2012) and about 47\% people do not have any shelter. Society faces numerous problems due to high population growth where housing along with other settlements is a notable concern. With the increase of family members, households are expanding their homesteads and this expansion is horizontal that leaves us with gradually decreasing agricultural lands in rural areas. Traditionally, Bangladeshi people in rural areas used to live in a Bari. Even though space availability for horizontal expansion is limited, people forced to do so considering high cost associated with vertical expansion. On the contrary, it is observed that people in urban areas usually expand their Bari vertically because the cost of vertical expansion is cheaper compared to the cost of land required for horizontal expansion. High growth rate of population in Bangladesh has created enormous pressure on land. In addition to that, land-use patterns are radically changing and adversely impacting country's agricultural land, forest, water bodies and wildlife habitat (Rahmatullah, 2007). Making new homes on cultivable land limits the use of land for agro production. According to 2011 estimates, the growth rate of population in Bangladesh is 1.37\% which stood $76^{\text {th }}$ among the countries in all over the world (Nabi, 2012). This high population requires huge amount of food every year. If such horizontal expansion trend is continued, it is expected that the food security of the country will become more vulnerable. Some of the studies further suggested that the land in rural areas under agriculture should not be used for any other purpose (Barakat et al., 2007). Existing literature deals with different aspects of housing in rural areas. However, very few of them considered housing from an indigenous perspective. Most of the studies devoted to analyze the socio-economic impacts of housing on cultivable land. However, at micro-level, the amount of cash forgone by a household for making 
homestead on cultivable land is significant. The benefit households derive from new homestead cannot offset such cash forgone. As a result, a question arises, the rationality behind the cash loss for housing. The current study has concentrated on utility derived by household and the economic efficiency gain as well as noneconomic loss of horizontal expansion of housing.

Horizontal and Vertical Expansion of Housing: Housing nowadays is considered as one of the major problems in the rural areas. With the increase of population all basic needs are required at higher amount including adequate space within households. In response to the problem of inadequacy of living space, villagers build new households on agricultural and other productive lands, which are known as horizontal expansion of housing. Land resource is limited in supply with extremely low price elasticity of supply though people seek an immediate solution of housing problem through horizontal expansion (Hertel, 2010). Apparently this expansion solves the problem in rural areas but leaves with some newly generated problems at the same time. The alternative way to expand living space is vertical expansion, which means increasing number of floors upward. Particularly it is very common in urban areas of Bangladesh, e.g. Dhaka, Chittagong, etc. Lots of high rise buildings are considered as vertical expansion of Bari in such areas (Ahmed \& Marjuk, 2013).

\section{Implications for Rural Housing in Bangladesh}

High growth rate of population and rapid urbanization in Bangladesh have created enormous pressure on country's agricultural land and ecological balance (Rahmatullah, 2007). People in rural areas build new homesteads on agricultural and other productive lands and its characteristic is regular and gradually increasing. Horizontal expansion of housing in rural areas is solving the part of the problem on the one hand but is again causing less agricultural production and few other inauspicious problems on the other hand e.g. climate change, deforestation, desertification and the loss of biodiversity. In addition, the availability of land per capita is decreasing, implying a further pressure on land. As a result, sustainable land use has become an important policy issue in Bangladesh. The present housing conditions and patterns in rural Bangladesh and the trend of shrinking cultivable land through horizontal expansion of housing has a great implication on the economy (Rahman and Manprasert, 2006). For proper land utilization the government could introduce a land management act with a land zoning system and a ceiling for housing in rural Bangladesh, as well as strengthen the housing facilities for disadvantaged people in a planned way (Rahman and Manprasert, 2006). When new residence is built in new homestead it puts pressure on the surrounding land. Sometimes new resident needs new pond, which grasps some more agricultural land. Owner of the land cannot cultivate the land properly due to homestead wastage on the land. The shadow of trees of the household reduces productivity of land as well (Rahman, 2012). The picture is not completed yet. The domestic animals of the household sometimes damage the crop of the land. These multiple negative impacts decrease the overall production and some impacts are long lasting too. Considering the situation, some researchers refer vertical expansion if horizontal expansion is not feasible (Jamil and Ahmed, 2006). The role of real estate companies is very essential in this regard but however, it is a matter of regret that such companies are not interested to expand their business in rural areas concerning the difficulties and profit gain compared to the urban areas.

Some researchers suggested finding some alternative ways of rural housing. Because, after agriculture, housing is the most important vehicle for the use of land due to increase in population, number of households, and increase in rural to urban migration, requiring enhanced quantum of land for housing (Rahmatullah, 2007). Some of the studies further suggested that land in rural areas under agriculture should not be used for any other purpose. Both unplanned and misuse of land are evident in Bangladesh. According to the surveys, about $25 \%$ acquisition of land remains unused or used in unproductive purposes. This type of misuse of land should be stopped. Size of land covered under irrigation has to be fixed on the availability of underground water. It will prevent desertification as well as ensure proper utilization of natural resources like water. Acquisition of land under irrigation has to be stopped strictly. Agricultural land with two or three cropping intensity or potentiality should be prohibited for non-agricultural uses such as private construction, housing, brick field etc. Non-agricultural Khas lands should be used on priority basis for nonagricultural development activities. Only in absence of alternatives, minimum amount of less fertile agricultural lands could be used for non-agricultural purposes (Barakat et al., 2007). Even in existing government policy related to making homes on arable land is not strictly implemented. A national policy paper related to the issue says, 'rural people 
would be discouraged to build new homes on arable land' (National Housing Authority, 2008). Thus existing literature deals with different aspects of housing and other settlements in rural area. However, none of these considered housing from an indigenous perspective. There might be some other facts behind constructing homes on cultivable land that people rationalize their decision based on. Perhaps people are compelled to do this sometimes. In order to take some policies to minimize horizontal expansion of housing in rural areas, government might consider native perspective as the present study anticipates. Otherwise the policy might be tough to be implemented.

The Research Problem and the Rationale of the Study: Housing on agricultural land in rural areas of Bangladesh is a common phenomenon. According to National Housing Policy 2010 (rough) the article 5.8.2 says that the housing on agricultural land will be discouraged. Once a house is built on agricultural land, the land goes out of crop production forever although it generates some other opportunities for the household. Consequently, an intimidation is created on the food security of the country. According to newspaper reports, many countries in the world especially Philippines has already imposed a restriction on the horizontal expansion of housing on agricultural land. But in Bangladesh, people can build new home at any place in the rural area without facing any legal ceiling. Although it generates loss of food grains and other crops, loss on environment and bio-diversity from a macroeconomic perspective; at micro level households do not consider such loss. They however derive some other returns both in cash and in kind from new homes. A pilot survey conducted in April'2011 reveals that people rationalize it in a number of ways. Thus non-agricultural use of agricultural land creates individual benefit at the cost of society as a whole. The social and economic cost of building new homestead on agricultural land or using agricultural land for non-agricultural purpose should be assessed in a systematic way. Knowledge about the households' perceptions regarding housing on cultivable land is a key determinant in formulating public policy to protect cultivable land. The current study has tried to address all these issues. Economists define utility not only in terms of money the person receives but also in terms of satisfaction one gains from an activity. As a pilot survey reveals, rural people mull over housing not only as a basic need but also a matter of prestige, an instrument of happiness, a place for entertainment. Thus economic loss to the society as a whole due to new homestead might be offset by the satisfaction the household derives by staying at new home. A study to find how people rationalize their activities in this context is immense need at present in Bangladesh.

Research Objectives and Hypothesis: The research has the following objectives-

- To compare between the cash return and cash investment of housing.

- To find how people residing new homes rationalize the economic loss of cultivable land.

- Moreover, the research has aimed to test the following hypothesis:

- The cash benefit received by households from housing on cultivable land is less than the cash foregone for housing.

Mean Test has been exercised to test this hypothesis.

$H_{0}: \mu_{1}=\mu_{2}$

$H_{1}: \mu_{1} \neq \mu_{2}$

\section{Methodology}

The study is a combination of both quantitative and qualitative in nature. It is principally based on a semi structured questionnaire and key informant technique, used to collect primary data. The area has been chosen from eastern part of Bangladesh, which is a village named Narayanpur under Manohargonj upazila in the district Comilla. High concentration of current research problem in the area worked as rationale of choosing this village beside the convenience of the researcher. A large number of new homesteads were built on agricultural land in last 20 years in the village as well as the surrounding villages (information provided by key informant-1). This period was selected as the Mouza map of the village prepared latest during the period of 1993 to 1998 through BS (Bangladesh Survey). Two key informants have been taken of which one is local surveyor (Key informant-1) and other is an educated person of the village graduated from Victoria College; a government approved old institution in Comilla under the National University (Key informant-2). All 29 households were interviewed who built new Bari on agricultural land after the year 1998 in this particular village. 


\section{Results and Discussion}

Cash Investment in Housing: We have estimated the present value of the investment in housing, using inflation adjustment. To compare with the cash returns received in the current period, such adjustment is done. In order to adjust the inflation we have used the 12 month average rate of inflation published by Bangladesh Bank (Table-1). The local inflation rate could be a better reflection of the reality in this connection. However, local inflation is neither calculated nor available in published format. The necessity of using 12-month average inflation is a vital one in this case. Households invested money for different expenditure of housing at different time periods. For instance, if a household had shifted in 2000, the household might have spent for land purchase in 1998, earth filling in 1999 and shifting re-fixing in 2000. Thus in order to compare the values in 2011 price we must adjust the inflation. We have used the inflation rate given in Table-1 to fine-tune the prices although it does not reflect the true local inflation. It is worthwhile to mention, local inflation as well as the rate of inflation in case of land price might be diverse from the 12-month average inflation.

Table 1: 12-Month Average Inflation from 1996-97 to 2010-11

\begin{tabular}{ll}
\hline Period & 12- Month Average Inflation \\
\hline $1996-97$ & 3.67 \\
$1997-98$ & 10.46 \\
$1998-99$ & 9.30 \\
$1999-00$ & 2.68 \\
$2000-01$ & 1.39 \\
$2001-02$ & 1.63 \\
$2002-03$ & 3.46 \\
$2003-04$ & 6.92 \\
$2004-05$ & 7.91 \\
$2005-06$ & 7.76 \\
$2006-07$ & 8.11 \\
$2007-08$ & 12.28 \\
$2008-09$ & 7.19 \\
$2009-10$ & 8.53 \\
$2010-11$ & 11.34 \\
\hline
\end{tabular}

Source: Bangladesh Bank Statistical Dataset (available at Bangladesh Bank website)

Table 2: Inflation Adjusted Average Expenditure by Household for New Homestead (In Thousand Taka)

\begin{tabular}{lllllllllll}
\hline $\begin{array}{l}\text { Land } \\
\text { Purchase }\end{array}$ & $\begin{array}{l}\text { Earth } \\
\text { Filling }\end{array}$ & $\begin{array}{l}\text { Shifting } \\
\text { and Re- } \\
\text { fixing }\end{array}$ & Gardening & $\begin{array}{l}\text { Making } \\
\text { New } \\
\text { House }\end{array}$ & $\begin{array}{l}\text { Tube- } \\
\text { well }\end{array}$ & $\begin{array}{l}\text { Shed for } \\
\text { Cattle and } \\
\text { Poultry }\end{array}$ & $\begin{array}{l}\text { Electricity } \\
\text { Connection }\end{array}$ & Others & Total \\
\hline 234.05 & 259.18 & 58.79 & 10.11 & 591.49 & 5.96 & 8.91 & 13.93 & 43.74 & 982.24 \\
\hline
\end{tabular}

Table-2 gives the inflation adjusted average expenditure by household for new homestead. Household spends for Land Purchase (if not owned), earth filling, shifting from earlier home and re-fixing at new homestead, gardening, making new house, tube-well, shed for either cattle and poultry or both, electricity connection and some other expenditures. Each household spends an amount of Tk. 234053.31 for land purchase according to 2011 price adjusted by inflation and an amount of Tk. 259183.46 for earth filling, on an average. The maximum expenditure goes for making new house at new homestead which stood at Tk. 591491.83 on an average after inflation adjustment. Moreover, the expense stood at Tk. 58795.17 and Tk. 10110 on an average for shifting \& re-fixing and gardening respectively. On the other hand, it took Tk. 5968.57 for tube-well, Tk. 8917.52 for making shed for cattle and poultry, Tk. 13935.72 for electricity connection and Tk. 42741.62 for other expenditures in 2011 prices. Finally, each household typically spends an amount of total Tk. 982247.36 for new housing on cultivable land at 2011 prices.

Cash Benefit Received by Household from New Home: Households receive both cash and non-cash benefits from new homesteads. However, the value of non-cash benefits is subjective. 
Table 3: Cash benefits received by households at new home on an average (2011 price) (In Thousand Taka)

\begin{tabular}{|c|c|c|c|c|c|c|c|c|}
\hline Garden & Fishing & Vegetables & Fruits & Live stocks & Poultry & $\begin{array}{l}\text { Capital Gain from } \\
\text { Land (per year) }\end{array}$ & $\begin{array}{l}\text { Other } \\
\text { Expenditure } \\
\text { Saved }\end{array}$ & Total \\
\hline 4.65 & 12.54 & 3.55 & 3.49 & 15.05 & 3.32 & 131.55 & 12.00 & 156.23 \\
\hline
\end{tabular}

Households receive some cash returns at new home given in Table-3. They derive cash reimbursements from gardening, fishing, vegetables, fruits, live stocks, poultry, capital gain from land, other expenditure saved etc. Table-3 illustrates, cash returns accrued to households on an average from different sources at new home. The maximum benefit is received from capital gain from land assets which stood at Tk. 131553.38 in 2011. This price is calculated from the current market price of per unit of land in the particular region of new homestead. This is a better reflection of the local inflation against the use of national inflation rate. The rationale for applying 2011 price instead of 2012 is very clear. Since the census was conducted during the period of April-May'2012 and there were 7-8 month remaining of that year, price information was not available for the then period. Buying price of a particular land is subtracted from current (2011) price to obtain the capital gain of that land. This is because of there is variations in land prices at different locations of the same village. As a result local price gives a more accurate picture of the inflation as well as capital gain than the national inflation rate as used in calculating the value of investment (Table-1 and Table-2).

Figure 1: Comparison between cash benefit and cash investment per year in 2011 price

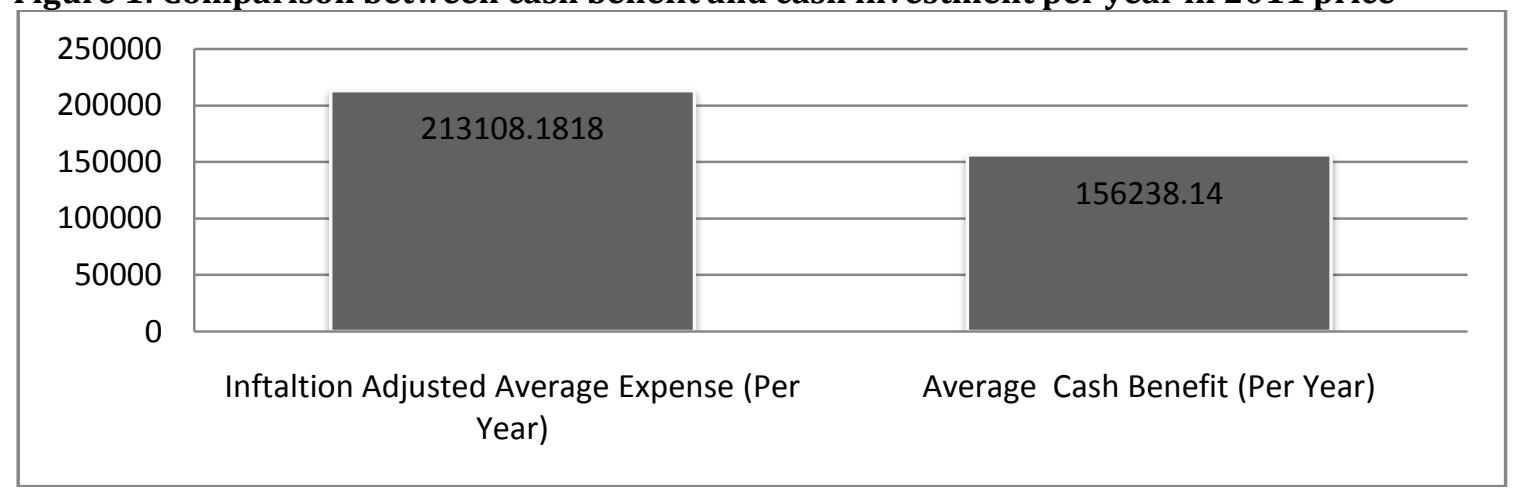

Comparison between Cash Return and Cash Investment: The data indentify that there is a gulf of difference between cash returns and cash investment per year in 2011 price. Figure- 1 shows a comparison between average cash benefits and cash investment per year in 2011 price received by each household from their new homestead. The difference stood on an average at an amount of Tk. 56870.04 per year for each household which is roughly $26.68 \%$ of the average investment by households for new housing. On an average, the cash benefit received by household at new place is Tk. 156238.14 per year in 2011 price and the cash investment per year in 2011price for housing is Tk. 213108.1818 (weighted average). This clearly indicates a cash loss from housing on cultivable land from household's perspective.

Table 4: No. of households receives profit and loss from new homestead

\begin{tabular}{lllll}
\hline $\begin{array}{l}\text { No. of Households } \\
\text { Receives Profit from New } \\
\text { Homestead }\end{array}$ & $\begin{array}{l}\text { No. of Households } \\
\text { Receives Loss from New } \\
\text { Homestead }\end{array}$ & $\begin{array}{l}\text { Missing No. of } \\
\text { Households }\end{array}$ & $\begin{array}{l}\text { Total No. of } \\
\text { Households }\end{array}$ \\
\hline 2 & 26 & 1 & 29 \\
\hline
\end{tabular}

Moreover, Table 4 shows that out of 29 households almost every households (actual number is 26 out of 29) receives cash loss from new housing. Only two households receive cash profit from new housing and another one household who shifted in 2012, yet to receive any cash benefit is shown as missing in Table-4. From the findings of Figure-1 it is clear; each household derives a cash loss on an average from the housing on cultivable land. Thus it becomes an important question whether the households' choice of making new home on cultivable land is a rational choice. Moreover, whether the decision is based on cash return from new homestead or something beyond cash benefits, is also one of the concerns of the study. 
Testing the Hypothesis: Mean Test: In order to test whether the difference between two values, expenditure and cash return are significantly different, we have used Mean Test.

$H_{0}: \mu_{1}=\mu_{2}$

$H_{1}: \mu_{1} \neq \mu_{2}$

For mean test, we used z statistic (Islam, 2008: 345). From our study using $z$ statistic, the calculated value of $z$ stood 1.29, which is smaller than the critical value of $z$ (1.96) at $5 \%$ level of significance. Thus we cannot reject the null hypothesis. Hence, statistically the cash investment for housing in rural area is not significantly different from the cash return received by the households.

Alternative Investments Available to the Households (Opportunity Cost): The amount on money households invested for new homesteads could have been used, for some other alternative purposes. They could receive a higher cash return per year from alternative sources than the housing. The situation is given in Table-5. In order to find the opportunity cost of investment in housing, we had to face some methodological complexities. Households were asked, about the available alternative investment opportunities without investing for housing. There are three types of answers from the respondents. The best available alternative investment for most of the households was investment in land assets. This is because, the value of land in the village increased substantially during the last two decades. The weighted average of capital gain from land purchased by each household is $259.61 \%$ per year in 2011 price (Table-5). Another alternative investment for the households was to make fixed deposit with the bank. For this, we used the compounding interest rate on a ten year fixed deposit of local bank (Agrani Bank) available for the households.

Table 5: Alternative Investment Return (Opportunity Cost) (In percentage)

\begin{tabular}{|c|c|c|c|}
\hline $\begin{array}{l}\text { Other Investment } \\
\text { (Purchasing Land) }\end{array}$ & Return-1 & $\begin{array}{l}\text { Other Investment Return-2 (10 years } \\
\text { fixed deposit with bank) }\end{array}$ & $\begin{array}{l}\text { Other Investment Return-3 } \\
\text { (Sending family member to } \\
\text { overseas employment) }\end{array}$ \\
\hline 259.61 & & 16 & 100 \\
\hline
\end{tabular}

The rate is roughly $16 \%$ per annum. Moreover, some of the respondents answered, they would have sent at least one of their family members for overseas employment, if they had not invested for housing. The weighted average of the return from overseas employment stood $100 \%$ per year. All the available investment opportunities before the households show positive cash return from the investments. Nonetheless, only two of the households received positive cash returns from investment in housing (Table-4). Thus it becomes also an important question, whether the choice made by most of the households for housing was a rational one.

Sources of Pain at New Home: During the interview, the households were asked about the sources of pain at new home. Table- 6 shows the frequency and the percentage of respondents given different answers. Out of twenty-nine respondents, six of them did not answer in this regard. Moreover, ten of them mentioned security problem at new home like theft and robbing. This security problem includes mental dissatisfaction to live in an isolated home, as I came to know during the interview with the respondents. Other four respondents mentioned their problems with the neighbors at new home. These neighbors include the land owners of the surrounding cultivable land. Neighbors often raise objection, regarding the damage induced by the new homestead. Such objection often leads deterioration of the social relationship between the households involved in this connection. It sometimes requires collective measures to solve the problem.

Table 6: Problems Faced by Households at New Home

\begin{tabular}{llll}
\hline Problems at New Home & Frequency & Percent & Cumulative Percent \\
\hline Missing & 6 & 20.7 & 20.7 \\
Security & 10 & 34.5 & 55.2 \\
Neighbors & 4 & 13.8 & 69.0 \\
Communication & 1 & 3.4 & 72.4 \\
Others & 3 & 10.3 & 82.8 \\
Both Security and Neighbors & 1 & 3.4 & 86.2 \\
No Problem Faced So Far & 4 & 13.8 & 100.0 \\
Total & 29 & 100.0 & \\
\hline
\end{tabular}


Although data from Table- 6 shows that only one respondent mentioned his problem regarding transport and communication. A good number of new homes do not have connection road in close proximity main road. During the rainy season, the isolated home seems to be a small island. Boat becomes the only mode of transportation for the dwellers of that home. Three other respondents mention some problems other than security, communication and neighbors. One of the respondents faces problems generated from both security and neighbors. In contrast, more than one-tenth (13.8\%) of the respondents answered that they do not face any problem at their new home.

\section{Figure 2: Incidence of Theft or Robbing at New Home}

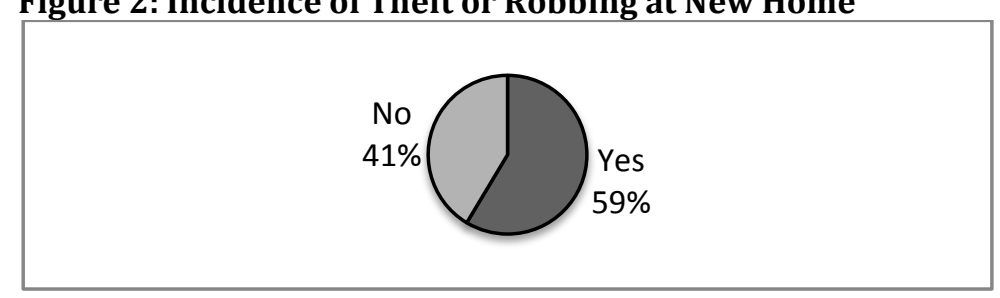

Incidence of Theft or Robbing at New Home: Figure-2 shows the incidence of theft or robbing faced by the respondents at new home, which is a major symbol of security problem. Nearly three-fifth (59\%) of the households faced incidence of theft or robbing at new home. Rest of the households did not face such problem yet. Thus it is clear from the figure; security problem is a big problem for majority of the households staying at new home.

Problems with Neighbors at New Home: After shifting to new homesteads, households face some problems with their neighbors. Such problem often leads to conflict that requires collective effort to bring a solution.

Incidence of Conflict: The study found that there are evidences of conflict with the new neighbors. The nature of the conflict includes ownership of land, crop damage by livestock and poultry, shadow created by the trees of new homestead on surrounding lands etc.

Figure 3: Incidence of Conflict with Neighbors at New Home

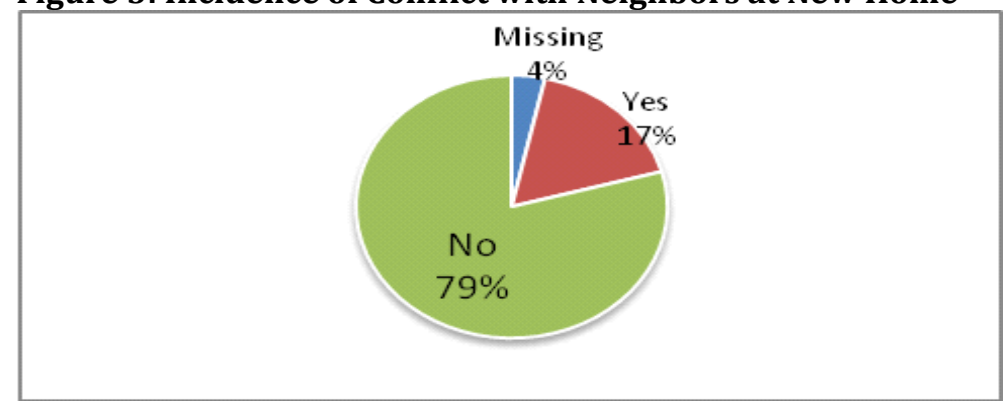

One of the respondent kept silence while answering the question. More than one-tenth of the households answered affirmative in this regard (Figure-3). However, nearly four-fifth of the households said that no conflict was arisen with the neighbors at their new home.

Payment as Compensation: One-tenth of the households had to pay compensation while collective efforts were taken to solve the conflict with neighbors (Figure-4). Most of the compensations were in cash rather than in kind.

Figure 4: Payment as Compensation 


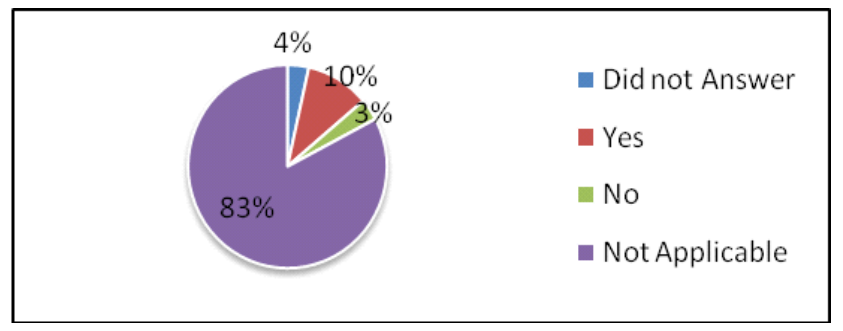

Transport and Communication Problem: Some of the households made their homes at such an isolated place where transport and communication is the major problem. They do not have any connection road with the nearby main road. During the rainy season they have to depend on boat as a medium of transportation. The new homes become some small islands during the rainy season.

Availability of Connection Road with Nearby Main Road: Some of the households failed to build a connection road between their new homes and the nearby main road. This is because the home is far away from the main road and the household does not have that much financial capability to make a road through the paddy fields. Moreover, few of the households faced severe problems at their earlier home, they did not think about a connection road while shifting. Building a new homestead at elsewhere was the major concern. The study has come across that nearly one-fifth of the households do not have a connection road with the main road at new home (Figure-5). Rest of households have connection road with the main road. Among them, a good number of households have built their homes beside the main road. As a result they do not require building a separate connection road.

\section{Figure 5: Availability of Connection Road between New Home and Main Road}

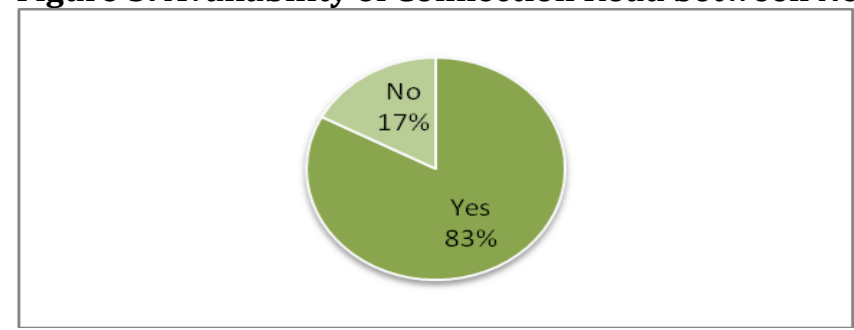

Availability of Electricity: Lack of availability of electricity at new home is another source of sufferings. As it is shown in Table-7 that more than one-third (34.5\%) of the households had electricity connection at their earlier home but the number decreased to less than one-fourth $(24.2 \%)$ at the new home.

Table 7: Availability of Electricity

\begin{tabular}{llllll}
\hline \multicolumn{2}{l}{ New Home } & \multicolumn{4}{l}{ Earlier Home } \\
\hline Result & Frequency & Percent & Result & Frequency & Percent \\
Yes & 7 & 24.1 & Yes & 10 & 34.5 \\
No & 22 & 75.9 & No & 19 & 65.5 \\
Total & 29 & 100.0 & Total & 29 & 100.0 \\
\hline
\end{tabular}

Rationalization of Choice: Households' rationalization becomes an important question after looking at the above discussions. Despite all the economic losses, opportunity costs as well as a number of pains, why the households made new homesteads on cultivable land. Is the choice of housing on cultivable land a rational one? How they view the costs and the pains at new homes. Whether they think they have done a good job by shifting to a new homestead. Moreover, the reasoning to make new home is consistent or not.

Reasons for Leaving the Opportunity Costs for Housing: We found from Table-5, households did not go for alternative investments despite a higher positive return. During the interview we asked the respondents why they did not go for such alternative investments. The answers are summarized in Table-8. 
Table 8: Reasons for Avoiding Alternative Investment

\begin{tabular}{llll}
\hline Reason & Frequency & Percent & Cumulative Percent \\
\hline Missing & 20 & 69.0 & 69.0 \\
Shifting Home was First Priority & 5 & 17.2 & 86.2 \\
Children's Future Consideration & 1 & 3.4 & 89.7 \\
Both Shifting and Children's Future & 1 & 3.4 & 93.1 \\
Honor and Dignity & 1 & 3.4 & 96.6 \\
Safety & 1 & 3.4 & 100.0 \\
Total & 29 & 100.0 & \\
\hline
\end{tabular}

According to the Table-8, although 20 households out of 29 are missing, the result gives an important insight about the rationalization by households, regarding their choice for housing on cultivable land. While talking with the respondents during the interview, we found them describing their necessity for a new home was the first priority among all other demands before shifting to new homesteads. One of them told us- Brother, we were almost suffocated at the previous home, the people around us, the environment; nothing was congenial for living there.' Further, the future betterment of their children was such a consideration that has multiple impacts on human life. At one stage of life, after earning a level of money, people want to achieve power, honor and dignity in his society. This is a rational choice widely used throughout the world. For some rich households, building new homestead meant asserting their identity. However, they could pass their life in their erstwhile homestead comfortably. They built new homesteads only to satisfy their ego. They shifted to a new homestead even leaving some cash profitable investment options. Safety is another concern to all the human beings. One of the households said shifting to new homestead was to ensure safety (Table-8).

Sources of Pleasure: Moreover, households rationalize their choice through their entertainment and pleasure. As we know throughout the world, people spend millions of money for their mental satisfaction through entertainment and different recreational activities. We found similar cases are prevailing here. Households unearth a more comfortable life at new homesteads; free from anxiety, chaos and quarrelling. The new home is full of silence, calm, open space, gentle breeze, freedom of choice, better natural environment. The households can bring their children up according to their own ideology, rather than being socialized in a cumbersome environment at earlier home. To conclude, it is clear from the above discussions, each household maximizes his/her non-cash benefits from new home. Such non-cash benefits are also termed as 'utility' (satisfaction) by the ordinal school of thought in economics. However, the non-cash benefits accrued to the households cannot be measured in number.

Acknowledgement of Society's Problem: It was tried to uncover, how the household view the problem stemming from the horizontal expansion of housing, accrues to the society as a whole. During the interview, the respondents were asked if they think, housing on cultivable land would cause a problem for the society as a whole. Since it is already established throughout the study, housing on cultivable land decreases the availability of land for cultivation in rural areas and creates a future threat on the food security of the country. As illustrated in Figure-6, more than two third (76\%) of the respondents acknowledge the problem faced by society as a whole due to horizontal expansion of housing.

\section{Figure 6: Acknowledgement of Negative Impacts on Society}

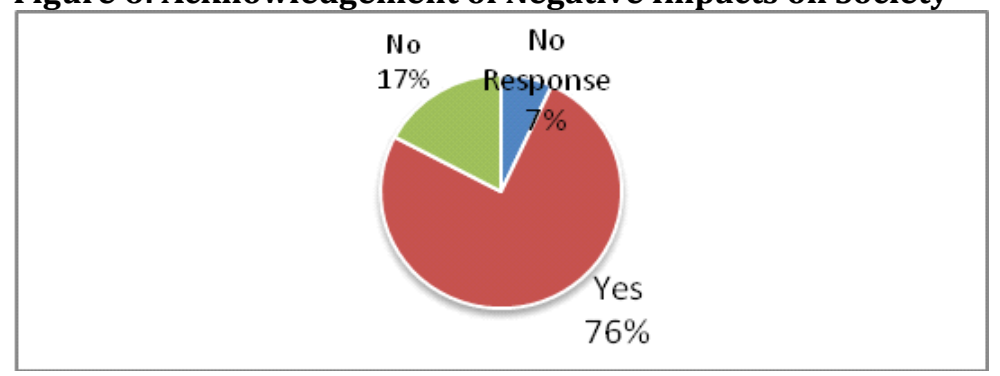

However, a less proportion (17\%) did not acknowledge the negative impacts of housing on the society as a whole. According to them, few homes on cultivable land can increase the agricultural outputs. Key informant- 
2 told us in this connection that the purpose of the interview was not clear to those particular respondents who answered negative, to this question. They thought, affirmative answer of such question might be used against them, as evidence by any other government authority. As a result they refused to acknowledge the negative impacts borne by the society in general. Even another $7 \%$ of the respondents kept silence, when they faced the question. This gives a critical insight of the rationalization of the choice, made by households. Although majority of the respondents acknowledged the negative impacts on the society as a whole, none of them had any regret in this regard. They feel their own returns are maximized despite a loss accrued to the society. Households' individual non-cash returns are maximized at new homesteads despite the cash loss and the loss of alternative opportunities, even the loss accrues to the society as a whole.

\section{Conclusion and Recommendations}

Although the study was based on a village from Bangladesh, it gives a number of insights regarding the issue of rural housing. In Narayanpur and the surrounding villages, every year a number of new homes are built on agricultural land. On an average, 1.93 homes are built in each year in the village for the duration of 1998 to 2012. The study finds that the households receive benefit both in cash as well as in kind from new homesteads made on cultivable land. Apart from this, some of the benefits accrue to the society as a whole. For instance, few cultivable lands were used to remain cultivable fallow for years after years before new homesteads were made to the adjacent areas. This is because; many of the lands were far away from the human settlement area as well as from water sources. After new homesteads were made on cultivable land, all the nearby land came under cultivation. However, such cultivation has been possible only for couple of homes in the village. The data indentify that there is a gulf of difference between cash returns and cash investment per year in 2011 price. The results of the study clearly indicate a cash loss from housing on cultivable land from household's perspective. However, statistically the cash investment for housing in rural area is not significantly different from the cash benefit received by the households at $5 \%$ level of significance. Thus it is clear that the households derive a cash loss on an average from the housing on cultivable land. Thus it becomes an important question whether the households' choice of making new home on cultivable land is a rational choice. Furthermore, household spends for new homestead despite the alternative profitable investment opportunities. Among the alternative investments, the best available alternative investment for most of the households was investment in land assets, the major opportunity cost of investment in housing. This is because the value of land in the village increased substantially during the last two decades. Another alternative investment for the households was to make fixed deposit with the bank. For this we used the compounding interest rate on a ten year fixed deposit of local bank (Agrani Bank) available for the households. The rate was $16 \%$ per annum. Moreover, some of the respondents answered that they would have sent their family member for overseas employment if they had not invested for housing. The weighted average of the return from overseas employment in the current study stood $100 \%$ per year. Thus it becomes also an important question whether the choice made by most of the households was a rational one.

The household faces some psychological, social, cultural sufferings at new homestead that is difficult to measure in number. Despite cash loss, loss of opportunity cost and a number of sufferings at the new home; household still rationalizes the choice of building new homestead. While talking with the respondents during the interview, we found them describing their necessity for a new home was the first priority among all other demands before shifting to new homesteads. In our study we also found, for some rich households, building a new homestead meant asserting their identity. However, they could pass their life in their erstwhile homestead comfortably. They built new homesteads only to satisfy their ego. It is clear from the above discussions; each household maximizes his/her non-cash returns from new home. Such non-cash returns are also termed as 'utility' (satisfaction) by the ordinal school of thought in economics. The non-cash returns accrue to the households cannot be measured in number. Although majority of the respondents acknowledged the negative impacts on the society as a whole, none of them had any regret in this regard. They feel their own returns are maximized despite a loss accrued to the society. Finally, it can be said that if the government or any authority is to take any step regarding the declining trend of cultivable land in rural areas, the socio-economic background of the households must be considered. The tendency towards making new homestead on cultivable land can be weakened through some counseling measures from the concern authority. NGOs can play vital roles in this regard. 


\section{Reference}

Ahmed, Z. \& Marzuk, A. O. (2013). Horizontal Expansion of Housing in Rural Areas of Bangladesh: Does Population Growth Matter? Developing Country Studies, 3(10).

Barakat, A., Ara, R., Taheruddin, M., Hoque, S. \& Islam, N. (2007). Towards a Feasible Land Use Policy of Bangladesh, Dhaka: HRDC.

Hertel, T. W. (2010). The Global Supply and Demand for Agricultural Land in 2050: A Perfect Storm in the Making? GTAP Working Paper No. 63, 2010, Available at https://www.gtap.agecon.purdue.edu/resources/download/5115.pdf.

Islam, M. N. (2008). An Introduction to Research Methods, Second Edition, Dhaka: Mullick Brothers

Jamil, G. M. H. \& Ahmed, M. (2006). Housing for Low Income People in Bangladesh: Problems and Prospects. The Cost and Management, 34 (5), 25-33.

Nabi, A. K. M. N. (2012). Demographic Trends in Bangladesh, Institute of Epidemiology, Disease Control and Research, Available at http://www.iedcr.org/pdf/files/NPHC\%20WEB/UPLOAD4/Dr.Nurun\%20Nabi.pdf.

National Housing Authority (2008). National Housing Policy [rough], Available at http://www.nha.gov.bd/pdf/national_housing_policy_(rough).pdf.

Rahman, M. A. (2012). Impact of Foreign Remittance on Land Holding and Land Relation in Rural Area of Bangladesh: A Case Study the Jirtoly, Village in the District of Noakhali [Draft] Dhaka: Department of Development Studies, University of Dhaka.

Rahman, M. D. H. \& Manprasert, S. (2006). Landlessness and its Impact on Economic Development: A Case Study on Bangladesh. Journal of Social Sciences, 2(2), 54-60

Rahmatullah, B. (2007). Broad Land Use Planning of Entire Bangladesh: A National Priority for Sustainable Development, Dhaka: Bangladesh.

Trading Economics (2012). Rural Population (\% Of Total Population) In Bangladesh, Available At http://www.tradingeconomics.com/bangladesh/rural-population-percent-of-total-population-wbdata.html. 